\title{
PENGARUH EKSPLOITASI SUMBER DAYA ALAM PERAIRAN TERHADAP KEMISKINAN PADA MASYARAKAT NELAYAN
}

\author{
Feryl Ilyasa ${ }^{1}$, Muhammad Zid ${ }^{2}$, Mieke Miarsyah ${ }^{3}$ \\ 1, Pendidikan Lingkungan, Pascasarjana Universitas Negeri Jakarta, \\ Komplek Universitas Negeri Jakarta Gedung M. Hatta Jl. Rawamangun Muka, Jakarta Timur, \\ Indonesia 13220, \\ email:feryl.ilyasa@yahoo.com \\ 2. Pendidikan Geografi, Universitas Negeri Jakarta, \\ Komplek Universitas Negeri Jakarta Gedung M. Hatta Jl. Rawamangun Muka, Jakarta Timur, \\ Indonesia 13220, \\ email : muhammadzid@unj.ac.id \\ ${ }^{3 .}$ Pendidikan Biologi, Universitas Negeri Jakarta, \\ Komplek Universitas Negeri Jakarta Gedung M. Hatta Jl. Rawamangun Muka, Jakarta Timur, \\ Indonesia 13220, email : mmiarsyah@unj.ac.id
}

\begin{abstract}
Abstrak
Tujuan dari penulisan artikel ini adalah untuk mengetahui bagaimana pengaruh dari eksploitasi sumber daya alam perairan terhadap kemiskinan masyarakat nelayan. Metode dalam penulisan artikel ini adalah menggunakan desain penelitian deskriptif dengan menggunakan pendekatan studi kepustakaan. Berdasarkan tipe penelitian dan jenis sumber data yang digunakan, maka teknik pengumpulan data dalam penelitian ini adalah menggunakan data-data sekunder. Hasil dari penelitian ini dapat dilihat pada dua aspek, yaitu: (1) mudahnya investasi pihak asing yang dapat mengeksploitasisumber daya alam perikanan di Indonesia; (2) pengaruh dari eksploitasi sumber daya alam perairan yang dilakukan terhadap kemiskinan pada masyarakat nelayan. Eksploitasi yang dilakukan terhadap sumber daya alam perairan yang ada di Indonesia disebabkan karena mudahnya pihak asing untuk melakukan investasi di Indonesia pada bidang perikanan, kemudahan investasi dari pihak asing ini mengakibatkan adanya campur tangan dari pihak asing yang dapat menguasai sumber daya alam perairan di Indonesia, baik itu dalam bentuk badan hukum ataupun dalam bentuk perseorangan, hal tersebut dapat ikut menguras sumber daya alam perairan terutama perikanan yang ada di Indonesia, yang dimana hal tersebut dapat mempengaruhi kesejahteraan masyarakat nelayan.
\end{abstract}

Kata kunci-Eksploitasi, Sumber Daya Alam Perairan, Kemiskinan, Masyarakat Nelayan

\begin{tabular}{|l|l|l|l|}
\hline Volume XXI & Nomor 1 & Maret 2020 & e-ISSN : 2580-9199 \\
\hline
\end{tabular}




\begin{abstract}
The aim of this article is to find out how the influence of exploitation of aquatic natural resources on the poverty of fishing communities. The method in this article used a descriptive research design for using a literature study approach. Based on the type of research and the type of data source used, the data collection technique in this study is used the secondary data. The results in this study can be seen in two aspects, are: (1) the ease of foreign investments that can be exploit for the natural resources of fisheries in Indonesia; (2) the influence of exploitation of the natural resources of the waters carried out on poverty in the fisihing community. Exploitation of aquatic natural resources in Indonesia is due to the ease with which foreign parties can be invest in Indonesia in the field of fisheries, and then this ease of investment from foreign parties results in the intervention of foreign parties who can to control the natural waters resources in Indonesia, both in the form a legal entitiy or in the form of an individual, it can be also for drain the natural waters resources, especially fisheries in Indonesia, and which can to be affect the walfare of fishing communities.
\end{abstract}

Keywords - Exploitation, Aquatic Natural Resources, Poverty, Fishing Communities

\section{PENDAHULUAN}

Negara Kesatuan Republik

Indonesia ini adalah sebuah Negara yang memiliki kekayaan alam yang sangat melimpah. Sumber Daya Alam baik yang bisa diperbarui maupun yang tidak bisa diperbarui adalah sumber daya yang sangat strategis bagi keberlangsungan kehidupan masyarakat. Hilangnya atau berkurangnya ketersediaan ini akan memiliki dampak yang sangat besar bagi keberlangusngan masyarakat Indonesia. Sumber Daya Alam ini adalah pemberian dari Tuhan Yang Maha Esa yang harus kita syukuri dan harus kita jaga dengan sebaik-baiknya agar untuk dapat dimanfaatkan oleh masyarakat (Mardani, 2016).

Indonesia merupakan Negara yang memiliki wilayah laut yang sangat luas, sehingga Negara ini dijuluki sebagai Negara maritime. Sebagai Negara maritime ini,
Indonesia juga memiliki lepas pantai yang terpanjang di dunia dengan panjang garis pantai lebih dari $104.000 \mathrm{~km}$ yang terdiri dari 17.504 buah pulau. Kemudian menurut data Kementerian Kelautan dan Perikanan (2011) menyatakan bahwa luas total Negara Indonesia adalah $7.827 .087 \mathrm{~km}^{2}$, dengan $3 / 4$ wilayahnya adalah laut dan pesisir dengan luas $\left(5,8\right.$ juta $\left.\mathrm{km}^{2}\right)$ yang terdiri atas 3 (tiga) bagian utama, yaitu Zona Ekonomi Eksklusif (ZEE) dengan luas 2,7 juta $\mathrm{km}^{2}$, Perairan Kepulauan dengan luas 2,8 juta $\mathrm{km}^{2}$ dan wilayah laut dengan luas 0,3 juta $\mathrm{km}^{2}$.

Dengan wilayah laut yang sangat luas ini, menjadikan negara Indonesia memiliki sumber daya alam laut yang sangat melimpah dan daya dukung lingkungan yang tinggi. Kemudian menurut Nurminingsih dan Wiganda (2010) dalam Ramlan dan Erwinsyahbana (2017) menyatakan bahwa pada tahun 2011 potensi lestari (Maximum 
Sustainable Yield) sumber daya alam perikanan laut di Indonesia diperkirakan sebesar 6,5 juta ton per tahunnya, hal tersebut terungkap berdasarkan kajian dari Badan Riset Kelautan dan Perikanan dan Pusat Penelitian dan Pengembangan Oseanologi Lembaga Ilmu Pengetahuan Indonesia.

Dengan melimpahnya Sumber Daya Alam perairan ini, berakibat menjadi sasaran utama dari investasi Negara lain. Menurut Data Badan koordinasi Penanaman Modal (BKPM) pada tahun 2011 yang telah dihimpun oleh Ramlan dan Erwinsyahbana (2017) menyatakan bahwa total investasi pada bidang perikanan pada tahun 2011 mencapai angka 1,2 juta Dollar Amerika dengan $100 \%$ adalah bersumber dari hasil investasi pihak asing. Yang kemudian angka investasi dari pihak asing ini terus mengalami kenaikan, hal ini berdasarkan Laporan Kegiatan Penanaman Modal (LKPM) pada tahun 2016 yang sudah dihimpun oleh Ramlan dan Erwinsyabana (2017) menyatakan bahwa realisasi penanaman modal asing pada bidang perikanan pada tahun 2012 terdiri dari 31 proyek dengan nilai investasi sebesar 29 juta Dollar Amerika, pada tahun 2013 terdiri dari 69 proyek dengan nilai investasi sebesar 10 juta Dollar Amerika, pada tahun 2014 terdiri dari 47 proyek dengan nilai investasi sebesar 35,3 juta Dollar Amerika, dan kemudian pada tahun 2015 terdiri dari 85 proyek dengan nilai investasi sebesar 53,1 juta Dollar Amerika.

Gambar 1. Eksploitasi Masif Di Laut Indonesia

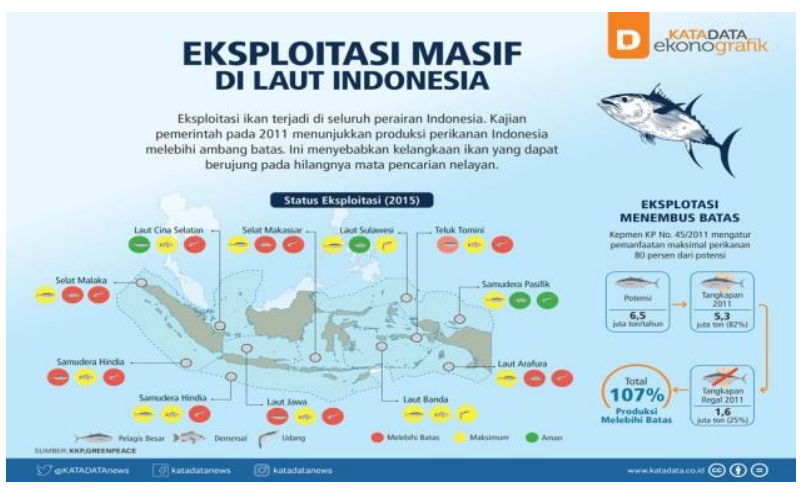

Sumber : Kata Data News (2017)

Berdasarkan gambar tersebut, menurut Nunes, Van den Bergh dan Nijikamp (2000) dalam Ramadhan dan Salim (2019) laut dan pesisir memiliki peran yang sangat strategis dan sangat penting bagi kesejahteraan manusia berkat manfaatmanfaat ekosistem yang didapatkan secara langsung maupun secara tidak langsung. Manfaat yang diberikan secara langsung tersebut merupakan aktivitas eksploitasi yang dilakukan oleh manusia terhadap sumber daya yang memberikan keuntungan secara ekonomi, hal tersebut juga termasuk dalam sebagai sumber makanan, energy dan kenayamana. Pada umumnya tipe manfaat secara langsung ini dapat dengan mudah dimonetisasi. Kemudian pada sisi lain, manfaat tidak langsung yang diperoleh oleh manusia dari keberadaan ekosistem laut dan pesisir ini adalah sebagai penyedia siklus 
nutrient, rantai makanan, dan berbagai fungsi ekologis lainnya.

Pemanfaatan jasa ekosistem laut dan pesisir ini yang dilakukan oleh beragam pihak untuk memenuhi kepentingan mereka yang berbeda-beda mengakibatkan adanya situasi yang sangat rawan terhadap konflik kepentingan. Seperti halnya pada penelitian yang dilakukan ole Mujio, Adrianto, Soewardi \& Wardianto (2016) yang menurut hasil penelitian mereka menemukan adanya konflik kepentingan antara bidang industry migas dengan aktivitas perikanan dan pariwisata bahari di pesisir Kota Bontang. Kemudian menurut Thomas (1979) menyatakan bahwa eksploitasi sumber daya alam adalah sebagai bentuk control manusia atas dunia melalui kekuasaan yang diberikan kepadanya. Pada konteks sumber daya laut dan pesisir control manusia ini juga dibatasi oleh sifat sumber daya alamnya yang bersifat barang public. Maka dari itu, upaya control yang dilakukan seseorang ini atau ekplootasi yang dilakukan ini dapat menimbulkan konflik dengan orang lainnya.

Dengan melakukan eksploitasi Sumber Daya Alam secara besar-besaran atau tidak terkendali dapat mengakibatkan rusaknya atau menurunnya dari kualitas lingkungan, yang dimana kuliats lingkungan tersebut dapat mempengaruhi kualitas penduduk/masyarakat. Tanpa adanya komitmen global, maka eksploitasi terhadap sumber daya alam ini memiliki dampak yang besar terhadap kualitas penduduk/masyarakat. Eksploitasi sumber daya alam yang mengabaikan lingkungan akan dapat mengancam keberlangsungan dan ketersediaan sumber daya alam tersebut. Menurut Meadow et al. (1972) dalam Rahadian (2016) menyatakan bahwa pertumbuhan ekonomi akan sangat dibatasi oleh ketersediaan dan kemampuan dari sumber daya alam. Dengan ketersediaan dan keterbatasan dari sumber daya alam tersebut, maka arus barang dan jasa yang dihasilkan dari sumber daya alam tidak bisa selalu dilakukan secara terus-menerus (On Sustainable Basis).

$$
\text { Menurut Daryanto (2007), }
$$

menyatakan bahwa seharusnya sumber daya alam pada bidang perikanan dapat dijadikan sebagai salah satu sumber yang penting bagi hajat hidup orang banyak dan juga memiliki potensi untuk dapat dijadikan sebagai penggerak utama (prime mover) bagi perekonomian nasional. Hal ini berdasarkan kepada kenyataan bahwa (Ramlan dan Erwinsyahbana, 2017) : (1) Indonesia memiliki sumber daya perikanan yang besar baik ditinjau dari kuantitas maupun diversitasnya; (2) industry pada bidang sector perikanan memiliki keterkaitan dengan sector-sektor lainnya; (3) industry perikanan berbasis sumber daya nasional atau dikenal dengan istilah national resources based 
industries, (4) Indonesia memiliki keunggulan (comparative advantage) yang tinggi pada sector perikanan sebagaimana dicerminkan dari potensi sumber daya alam yang ada.

Berbagai kajian maupun penelitian yang sudah dilakukan selama ini yang berkaitan dengan kehidupan social ekonomi masyrakat nelayan telah memberikan kita fakta bahwa sebagian besar dari mereka masuk ke dalam golongan buruh atau nelayan-nelayan kecil yang hidup dalam keterbatasan. Kemampuan mereka untuk dapat memenuhi kebutuhan hidup mereka sehari-hari sangat terbatas atau bahkan sangat sulit. Bagi masyarakat nelayan, beberapa jenis kebutuhan pokok kehidupan, yang paling penting dan wajib untuk dapat selalu dipenuhi adalah kebutuhan pangan. Adanya kelangsungan pemenuhan kebutuhan pangan setiap harinya sangat penting bagi mereka untuk dapat menjaga kelangsungan hidup mereka (Muryato, dkk, 1984; Kusnadi, 2002) dalam Anwar dan Wahyuni (2019).

Walaupun para nelayan tersebut mengambil peranan yang sangat penting dalam meningkatkan produktivitas perikanan nasional, tetapi hal tersebut tidaklah dapat membawa suatu korelasi yang bersifat posistif terhadap peningkatan kesejahteraan social mereka. Dan hal ini diperburuk dengan banyaknya peran-peran pihak asing dalam melakukan monopoli terhadap perikanan
Indonesia. Tetapi monopoli tersebut yang dilakukan oleh pihak asing terhadap perikanan Indonesia sampai saat ini tidak dapat memberikan kontribusi yang sangat berarti kepada peningkatan kesejahteraan masyrakat nelayan Indonesia. Hal tersebut bahkan berefek sebaliknya, bahwa industry pada bidang perikanan yang dijalankan oleh masyarakat nelayan Indonesia sudah banyak yang mengalami kebangkrutan atau tutup usaha yang diakibatkan karena kekurangan bahan baku (ikan). Tujuan dari penulisan artikel ini adalah untuk mengetahui bagaimana pengaruh dari eksploitasi sumber daya alam perairan terhadap kemiskinan masyarakat nelayan.

Berdasarkan uraian dari latar belakang tersebut, maka yang menjadi permasalahan yang dibahas dalam artikel ini adalah bagaimana pengaruh dari eksploitasi sumber daya alam perairan terhadap kemiskinan dari masyarakat nelayan ?

\section{METODOLOGI PENELITIAN}

Penelitian ini menggunakan desain penelitian Deskriptif dengan menggunakan pendekatan Studi Kepustakaan. Penggunaan desain penelitian Deskriptif ini dalam penelitian bertujuan untuk mengetahui bagaimana pengaruh eksploitasi sumber daya alam perairan terhadap kemiskinan dari masyarakat nelayan. Pengumpulan data adalah prosedur yang sistematis dan standar 
untuk memperoleh sebuah data. Berkaitan dengan hal tersebut, berdasarkan tipe penelitian dan jenis sumber data yang digunakan dan yang sudah ditetapkan, maka teknik pengumpulan data dalam penelitian ini adalah menggunakan data-data sekunder, baik dari hasil penelitian orang lain maupun dari website resmi milik pemerintah dan dari berita-berita terpercaya.

\section{HASIL DAN PEMBAHASAN}

1. Hasil

\section{a. Data Luas Wilayah Negara}

Kesatuan Republik Indonesia

1) Luas Wilayah Total NKRI

$$
\text { : 7,8 Juta } \mathrm{Km}^{2}
$$

2) Luas Pesisir dan Wilayah Laut

$$
\text { : 5,8 Juta } \mathrm{Km}^{2}
$$

3) Luas Zona Ekonomi Ekslusif

$$
\text { : 2,7 Juta } \mathrm{Km}^{2}
$$

4) Luas Wilayah Perairan Teritorial

$$
\text { : 3,1 Juta } \mathrm{Km}^{2}
$$

Sumber : UNCLOS (1982)

dalam Ramadhan dan Arifin (2013)

b. Data Investasi Pihak Asing Pada

Bidang Perikanan di Indonesia

Tabel 1. Data Investasi Pihak Asing

Pada Bidang Perikanan di Indonesia

\begin{tabular}{|c|c|c|}
\hline Tahun & Nilai & Jumlah \\
& Investasi & Proyek \\
& (Juta & \\
& Dollar) & \\
\hline
\end{tabular}

\begin{tabular}{|c|c|c|}
\hline 2012 & 29 & 31 \\
\hline 2013 & 10 & 69 \\
\hline 2014 & 35,3 & 47 \\
\hline 2015 & 53,1 & 85 \\
\hline
\end{tabular}

Sumber : BKPM (2016) dalam

Ramlan dan Erwinsyahbana (2017)

\section{c. Potensi Lestari Perikanan}

Tangkap di Indonesia

1) Tahun $2011:$ : 6,4 Juta ton/tahun

2) Tahun $2016:$ 6,5 Juta ton/tahun

3) Tahun $2019 \quad$ : 12,54 Juta ton/tahun

Sumber : Nurminingsih dan Wiganda (2010) dalam Ramlan dan Erwinsyahbana (2017), Setkab.go.id (2016) dan Cendana News (2019)

\section{d. Data Kemiskinan Masyarakat}

\section{Nelayan di Indonesia}

1) Jumlah Penduduk Miskin pada tahun $2008 \quad$ : 34,96 Juta Jiwa

2) Jumlah Penduduk Miskin pada tahun 2017 : 26 Juta Jiwa

3) Jumlah Penduduk Miskin Nelayan pada tahun 2008 : 7,8 Juta Jiwa

4) Jumlah Penduduk Miskin Nelayan pada tahun $2011: 7,87$ Juta Jiwa 
Sumber : Sekretariat Wakil

Presiden Republik Indonesia

(2011), Okezone.com (2014) dan BPS (2018)

2. Pembahasan

a. Mudahnya Investasi Pihak Asing Yang Dapat Mengeksploitasi Sumber Daya Alam Perikanan Indonesia

Menurut Ramlan dan Erwinsyahbana (2017) adanya campur tangan (investasi) dari pihak asing yang dapat menguasai sumber daya alam perikanan Indonesia baik dalam bentuk badan hukum ataupun dalam bentuk perseorangan, hal tersebut dapat ikut menguras sumber daya alam perikanan yang ada di Indonesia. Mudahnya investasi yang berasal dari pihak asing sejak dulu sampai saat ini pihak asing diberikan izin untuk ikut campur dalam melakukan pengelolaan secara langsung industry-industri perikanan yang ada di Indonesia. Selain kemudahan berinvestasi bagi pihak asing di Indonesia, alasan lain yang kuat bahwa para investor asing tersebut tertarik untuk berinvestasi di Indonesia adalah karena potensipotensi lestari perikanan yang dimiliki oleh Indonesia sangatlah besar. Berdasarkan data-data dari berbagai sumber yang didapatkan dapat diketahui bahwa potensi lestari perikanan tangkap di Indonesia terus mengalami kenaikan, seperti pada tahun 2011, potensi lestari perikanan di Indonesia sebesar 6,4 juta ton/tahun, pada tahun 2016 potensi lestari perikanan sebesar 6,5 juta ton/tahun dan kemudian pada tahun 2019, potensi lestari perikanan sebesar 12,54 juta ton/tahun.

Kemudahan berinvestasi bagi pihak asing di Indonesia dapat dilihat dalam Undang-Undang No. 45 Tahun 2009 tentang Perikanan yang telah menggantikan UndangUndang lama yang sebelumnya, yaitu Undang-Undang No. 9 Tahun 1985 dan Undang-Undang No. 31 Tahun 2004. Berkaitan dengan hal tersebut dalam pasal 4 UndangUndang No. 45 Tahun 2009 ditentukan bahwa Undang-Undang ini berlaku untuk :

a) Setiap orang, baik warga Negara Indonesia maupun warga Negara asing dan badan hukum Indonesia maupun badan hukum asing yang melakukan kegiatan perikanan di wilayah pengelolaan perikanan Republik Indonesia. 
b) Setiap kapal perikanan yang memiliki bendera Indonesia dan kapal perikanan yang memiliki bendera asing yang melakukan kegiatan perikanan di wilayah pengelolaan perikanan Republik Indonesia.

c) Setiap kapal perikanan yang memiliki bendera Indonesia yang melakukan penangkapan ikan di luar wilayah pengelolaan perikanan Republik Indonesia dan;

d) Setiap kapal perikanan yang memiliki bendera Indonesia yang melakukan penangkapan ikan, baik secara perorangan/sendiri-sendiri maupun kelompok/bersamasama dalam bentuk kerja sama dengan pihak asing.

Dari hal tersebut dapat diketahui bahwa, Indonesia membuka peluang yang sangat lebar bagi pihak asing untuk berinvestasi dalam bidang perikanan dan ikut secara langsung dalam melakukan pengelolaan perikanan di Indonesia. Kemudahan pihak asing dalam melakukan investasi dalam bidang perikanan di Indonesia didukung dengan adanya ketentuan dalam Peraturan Presiden No. 44 Tahun
2016 tentang Daftar Bidang Usaha yang Tertutup dan Bidang Usaha yang Terbuka dengan Persyaratan di Bidang Usaha Penanaman Modal. Kemudahan investasi yang dibuka oleh pemerintah Indonesia kepada pihak asing berdasarkan data yang sudah dikutip oleh Ramlan dan Erwinsyahbana (2017) dari BKPM (2016) bahwa selang waktu mulai dari tahun 2012 sampai dengan tahun 2015 nilai investasi dari pihak asing terus mengalami kenaikan, walaupun pada tahun 2013 nilai investasi asing mengalami penurunan yang cukup tajam, yaitu sebesar 19 juta Dollar Amerika. Dan nilai investasi asing yang besar ini diikuti dengan banyaknya proyekproyek yang pada tahun 2012 sampai dengan $2015 \quad$ mengalami peningkatan, walaupun pada tahun 2014 jumlah proyek-proyek tersebut mengalami penurunan, tetapi jumlah penurunan ini tidak terlalu signifikan, yaitu sebesar 22 proyek.

Dalam lampiran Peraturan Presiden No, 44 Tahun 2016 tersebut menyatakan bahwa dengan cara kemitraan pihak asing dibenarkan untuk melakukan investasi (menanamkan modal secara 
langsung) pada beberapa bidang usaha, seperti :

a) Pembersihan ikan laut, ikan air payau dan ikan air tawar.

b) Pembesaran ikan laut, ikan air payau dan ikan air tawar.

c) Usaha pengelolaan hasil perikanan, terdiri dari industry penggaraman/pengeringan ikan, pengasapan ikan dan biota perairan yang lainnya, yang kemudian industry peragian/fermentasi ikan dan produksi masak lainnya (untuk usaha ekstraksi dan jelly ikan), serta industry yang berbasis daging lumatan dan surimi.

d) Usaha pemasaran, distribusi, perdagangan besar dan ekspor hasil perikanan.

Kemudian maksud dari kata kemitraan dapat kita temukan dalam pasal 25 Peraturan Pemerintah No. 17 Tahun 2013 tentang Pelaksanaan UndangUndang No. 20 Tahun 2008 tentang Usaha Mikro, Kecil dan Menengah yang menentukan :

a) Usaha mikro, usaha kecil ataupun usaha menengah local dalam hal pelaksanaan kegiatan usahanya dapat melakukan kemitraan usaha dengan usaha yang lebih besar pada pihak asing dengan melalui pola usaha patungan (joint venture) dengan cara menjalankan aktifitas ekonomi bersama dengan cara mendirikan perusahaan baru.

b) Usaha mikro dan usaha kecil local dalam melaksanakan kegiatannya usahanya dapat melakukan kemitraan usaha dengan usaha menengah dari pihak asing melalui pola usaha patungan (joint venture) dengan cara menjalankan aktifitas ekonomi bersama dengan cara mendirikan perusahaan baru.

Kemudian pengertian dari joint venture tersebut yang berdasarkan penjelasan pada pasal 11 Peraturan Pemerintah No. 17 Tahun 2013 tentang Pelaksanaan Undang-Undang No. 20 Tahun 2008 adalah bahwa kemitraan yang dilakukan dengan cara menerapkan usaha mikro dan usaha kecil dari pihak Indonesia yang menjalin kerjasama dengan usaha menengah dan usaha besar dari pihak asing untuk dapat menjalankan aktifitas ekonomi secara bersama-sama yan $\mathrm{g}$ masing-masing pihak memberikan kontribusi modal saham dengan cara mendirikan badan hukum perseroan 
terbatas dan berbagi secara adil tehadap keuntungan dan /atau risiko kerugian dari perusahaan.

Dari hal-hal tersebut di atas, sangat jelas bahwa para investor dari pihak asing memiliki kesempatan yang sangat terbuka lebar untuk dapat menanamkan modalnya pada bidang perikanan dari Sabang sampai Merauke. Dan apabila kita lihat kembali, ketentuan yang tertuang dalam pasal 4 Undang-Undang No. 45 Tahun 2009 tentang Perikanan dan juga Peraturan Presiden No. 44 Tahun 2016, sangat jelas bertentangan dengan pasal 29 ayat 1 UndangUndang No. 45 Tahun 2009 tentang Perikanan yang dengan tegas menyatakan bahwa usaha perikanan pada wilayah pengelolaan perikanan yang ada di Republic Indonesia hanya boleh dilakukan oleh warga Negara Indonesia atau badan hukum miliki Indonesia.

Pasal 29 ayat 1 UndangUndang No. 45 Tahun 2009 tentang Perikanan ini adalah bentuk dari perwujudan daripada tujuan Negara dalam meningkatkan kesejahteraan yang tertuang dalam pembukaan Undang-Undang Dasar 1945 alinea ke-4, yang dimana Negara harus aktif dalam mengupayakan tercapainya kesejahteraan, bertindak adil yang dapat dirasakan bagi seluruh masyarakat, terkhusus masyarakat nelayan dan para pelaku industry perikanan yang ada di Indonesia secara merata dan berimbang, dan bukan mensejahterakan golongangolongan atau pihak-pihak tertentu saja (khususnya pihak asing), tetapi bagi seluruh rakyat, sehingga tidak adanya satupun masyarakat (khususnya masyarakat nelayan) yang mengalami penderitaan atau bahkan dibiarkan menderita begitu saja baik dari segi ekonomi maupun social tanpa adanya solusi untuk dapat mengatasi permasalahan tersebut.

\section{b. Pengaruh Eksploitasi Sumber Daya Alam Perairan Terhadap Kemiskinan Pada Masyarakat Nelayan}

Saat ini perhatian utama dari dunia internasional adalah permasalahan lingkungan yang sangat dapat mempengaruhi pertumbuhan ekonomi dunia. Negara-Negara maju lainnya sangat menyadari bahwa memacu pertumbuhan ekonomi dan pembangunan memiliki dampak 
secara langsung terhadap rusaknya alam atau rusaknya lingkungan yang dimana rusaknya lingkungan ini dapat mengganggu dan menghambat pertumbuhan dan kelangsungan hidup manusia (Haller, 2012). Dalam hal memacu pertumbuhan ekonomi tidak terlepas dari adanya upaya-upaya yang dilakukan oleh para pembuat kebijakan di berbagai belahan dunia dengan tujuan untuk menciptakan kemakmuran, mengentaskan kemiskinan dan menciptakan lapangan pekerjaan yang layak bagi para penduduk di Negara-negara tersebut (Leonada, 2019).

Secara garis besarnya terdapat dua dimensi dalam kemiskinan menurut Prayitno dan Budi Santoso, 1996) dalam Anwar dan Wahyuni (2019), yaitu : (1) kemiskinan multi dimensional, yaitu berupa miskin akan asset-aset, pengetahuan/keterampilan, tidak memiliki sumber dana dan akses informasi. Kemiskinan dalam dimensi ini memanifestasikan diri dalam bentuk kurangnya gizi, air dan perumahan yang tidak sehat, perwatan kesehatan yang kurang baik serta memiliki pendidikan yang rendah; (2) aspek kemiskinan yang muncul dari factor manusiannya, baik secara individu/perorangan maupun secara kolektif/kelompok.

Apabila kita berbiacara terkait kemiskinan, maka akan ada banyak sekali definisi yang kita dapatkan dari kemiskinan, tetapi secara garis besarnya dapat dikatakan bahwa penggunaan istilah kemiskinan ini selalu menunjuk kepada suatu kondisi yang serba kekuarangan. Baik dilihat dari aspek ekonomi, ataupun aspek social dan budaya. Kemudian dalam pandangan sosiologi, kemiskinan adalah suatu keadaan yang dimana seseorang itu tidak memiliki kesanggupan untuk dapat memelihara dirinya sendiri yang disesuaikan dengan taraf kehidupan kelompok dan juga tidak memiliki kesanggupan untuk dapat memanfaatkan tenaga, mental ataupun fisiknya dalam kelompok tersebut (Soekanto, 2006). Penggunaan definisi dari kemiskinan ini adalah ciri yang sangat menonjol daripada kehidupan masyrakat yang tinggal di wilayah pesisir yang masih enggan untuk menjauh dari kehidupan menjadi seorang nelayan. 
Berdasarkan data

Sekretariat Wakil Presiden Republik

Indonesia (2011) jumlah penduduk miskin di indonesia berjumlah sebanyak 34,96 juta jiwa dan berdasarkan data dari Badan Pusat Statistik (2017) jumlah dari penduduk miskin di Indonesia mengalami penurunan yang cukup signifikan berjumlah sebanyak 26 juta jiwa. Kemudian data terkait masyarakat nelayan yang miskin menurut Sekretariat Wakil Presiden Republik Indonesia (2011) berjumlah sebanyak 7,8 juta jiwa dan berdasarkan data Badan Pusat Statistik (2011) yang dikutip oleh berita Okezone.com jumlah masyarakat nelayan yang miskin mengalami sedikit kenaikan yaitu berjumlah sebanyak 7,87 juta jiwa.

Menurut Kompas (2019) yang telah dihimpun oleh Anwar dan Wahyuni (2019) menyatakan bahwa masyarakat nelayan adalah salah satu kelompok social masyarakat atau social penduduk atau komunitas yang selama ini terpinggirkan baik secara social, ekonomi maupun politik dan teridentifikasi miskin yang memiliki pendapatan yang rendah atau dibawah rata-rata nilai minimum, sehingga sangat wajar apabila banyak orang yang mengidentifikasi mereka sebagai The Poorest of The Poor. Kemudian kurang dari 14,58 juta jiwa atau sekitar 90\% dari 16,2 juta dari jumlah masyarakat nelayan dari wilayah Sabang sampai Merauke belum memiliki daya secara ekonomi maupun politik dan mayarakat nelayan ini sangat banyak sekali yang berada di bawah garis kemiskinan.

\section{Sumber}

penghasilan/pendapatan dari masyarakat nelayan berbasis dari perairan yang merupakan bagian integral dari bangsa ini yang dapat menjadi ujung tombak dari pemberdayaan sumber daya sub bidang perairan dan kelautan dalam hal mengisi pembangunan ekonomi Indonesia. Peran yang sangat strategis ini dari masyarakat nelayan dalam mengisi pembangunan ekonomi tersebut haruslah dapat terwujud apabila masyarakat nelayan ini diberdayakan, diakui, dilindungi dan memiliki jaminan atas kepastian hukum yang bisa berpihak kepada mereka yang memiliki sumber utama penghidupan mereka yang berasal dari perairan (Anwar dan Wahyuni, 
2019). Kehidupan dari masyarakat nelayan ini sangatlah menyedihkan dan membuat kita menjadi merasa kasihan, karena sebagai nekayan yang tergolong ke dalam kelompok masyarakat mereka seringsekali dijadikan sebagai objek eksploitasi oleh para pemilik modal atau para pedagang tengkulak, sehingga distribusi pendapatan mereka menjadi tidak merata.

Berdasarkan berita dari Kompas (2019) yang dikutip oleh Anwar dan Wahyuni (2019) menyatakan bahwa berdasarkan data dari Kementerian Perhubungan, jumlah nelayan yang memiliki sertifikasi per-februari 2019 telah mencapai angka 232.414. tetapi dalam 10 tahun terakhir ini jumlah nelayan berkurang sebesar $25 \%$. Jumlah menjadi sekitar 2,8 juta kepala keluarga nelayan tangkap di laut. Kemudian ada beberapa factor yang menyebabkan terjadinya penurunan yang cukup signifikan terhadap jumlah nelayan yang berdasarkan temuan-temuan dari beberapa daerah, yaitu : (1) disebabkan karena kebijakan yang tidak menguntungkan, hal ini karena memang ada pengabaian yang dilakukan oleh pemerintah ataupun dilakukan oleh pihak industry yang melakukan pencemaran terhadap laut; (2) adanya praktik pengusiran, hal ini jelas terlihat pada kawasan industry pariwisata yang dimana nelayan-nelayan tidak boleh menangkap ikan dengan alasan wilayah pariwisata. Sedangkan menurut data dari Kementerian Kelautan dan Perikanan pada tahun 2018 menunjukkan, bahwa jumlah nelayan dari Sabang sampai Merauke berjumlah 2,7 juta orang. Berdasarkan jumlah tersebut, mayoritas berada dalam ambang batas kemiskinan dan menyumbang sebesar $25 \%$ angka kemiskinan secara skala Nasional.

\section{KESIMPULAN}

Berdasarkan pembahasan yang sudah dipaparkan sebelumnya, maka dapat ditarik beberapa kesimpulan, yaitu : (1) eksploitasi sumber daya alam perairan banyak dilakukan oleh perusahaanperusahaan besar milik asing, mulai dari hulu sampai ke hilir dengan menggunakan kemitraan/kerja sama; (2) pemerintah Indonesia memudahkan jalan investasi bagi pihak asing untuk dapat mengelola sumber daya alam perairan yang ada di Indonesia; (3) kemiskinan yang banyak terjadi pada masyarakat nelayan sebagai akibat dari lemahnya kemampuan modal, terbatasnya 
penguasaan pengetahuan dan teknologi dari pengelolaan hasil tangkap dan karena majunya teknologi yang dimiliki kapal nelayan asing yang menangkan ikan dengan cara yang illegal; (4) kebijakan yang dibuat oleh para pembuat kebijakan tidak berpihak kepada nasib masyarakat miskin nelayan.

\section{SARAN}

Berdasarkan kesimpulan yang telah dibuat, maka penulis memberikan beberapa saran, yaitu : (1) pemerintah harus selalu melakukan control atau pengawasan secara berkala terhadap perusahaan-perusahaan besar milik asing guna terhindarnya aktivitas eksploitasi secara berlebihan terhadap sumber daya alam perairan; (2) batasi porsi investasi bagi pihak asing untuk dapat mengelola sumber daya alam perairan yang ada di Indonesia; (3) melakukan pemberdayaan kepada masyarakat miskin nelayan, terkait pemberian informasi, pengolahan hasil tangkapan dan pemberian modal dari pemerintah; (4) kebijakan yang dibuat haruslah dapat berpihak kepada nasib masyarakat nelayan yang miskin.

\section{DAFTAR PUSTAKA}

Amin, M. (2019). Potensi Lestari Perikanan Tangkap Indonesia Capai 12,54 Juta Ton.

https://www.cendananews.com/2019 /11/potensi-lestari-perikanantangkap-indonesia-capai-1254-jutaton.html. Diakses pada tanggal 21 Januari 2020. Pukul 13.00 WIB.

Anwar, Z, dan Wahyuni. (2019). Miskin Di Laut Yang Kaya : Nelayan Indonesia
Dan Kemiskinan. Jurnal Sosioreligius. No. IV. Vol. 1, Juni 2019.

Badan Pusat Statistik, (2018). Jumlah Penduduk Miskin, Presentase Penduduk Miskin dan Garis Kemiskinan, 1970-2017. https://www.bps.go.id/statictable/201 4/01/30/1494/jumlah-pendudukmiskin-persentase-penduduk-miskindan-garis-kemiskinan-19702017.html. Diakses pada tanggal 22 Januari 2020. Pukul 11.00 WIB.

Daryanto, A. (2007). Dari Klaster Menuju Peningkatan Daya Saing Industri Perikanan. Buletin Craby \& Stark. Edisi Januari.

Haller, L.P. (2012). Concepts of Economic Growth and Development. Challenges of Crisis and of Knowledge. Economy Transdiciplinarity Cognition. Vol. 15, Issue 1/2012. Page 66-71.

Hartriani, J. (2017). Eksploitasi Masif di Laut Indonesia: Penangkapan Berlebih Merupakan Eksploitasi Ikan Yang Melampaui Kemampuan Untuk Beregenerasi Secara Lestari. https://katadata.co.id/infografik/2017 /02/17/eksploitasi-masif-di-lautindonesia. Diakses pada tanggal 21 Januari 2020. Pukul 11.00 WIB.

Humas, (2016). Potensi Besar Perikanan Tangkap Indonesia. https://setkab.go.id/potensi-besar perikanan-tangkapindonesia/?yop_poll_tr_id=\&yoppollnonce1_yp586378ba146a3=3ffa51bf

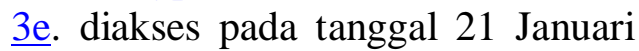
2020. Pukul 14.00 WIB.

Jannah Kurniasih, M. (2014). 25\% Penduduk Miskin Adalah Nelayan. https://economy.okezone.com/read/2 014/11/24/320/1069854/25penduduk-miskin-adalah-nelayan. Diakses pada tanggal 21 Januari 2020. Pukul 11.00 WIB. 
Kementerian Kelautan dan Perikanan. (2011). Data Pokok Kelautan dan Perikanan Periode s.d. Oktober 2011. Jakarta: tp.

Leonada, B. D. (2019). Masalah Lingkungan, Pemanasan Global dan Masa Depan Industri Kelapa Sawit Indonesia. [Edisi Khusus]. Buletin Profesi Insinyur 2(3) : 102-107.

Mardani Anggi, A. (2016). Analisis Eksploitasi Sumber Daya Alam Guna Meningkatkan Kesejahteraan Masyrakat Dalam Perspektif Ekonomi Islam. Skripsi. Fakultas Ekonomi dan Bisnis Islam. Universitas Islam Negeri (UIN) Eaden Intan Lampung. 2016.

Mujio. L, Adrianto. K, Soewardi dan Wardiatno. Y. (2016). Analisis Potensi Konflik Pemanfaatan Ruang Kawasan Pesisir : Integrasi Rencana Tata Ruang Darat dan Perairan Pesisir. Jurnal Sosiologi Pedesaan. Agustus 2016, hal : 139-144.

Rahadian, A.H. (2016). Stretegi Pembangunan Berkelanjutan.
Prosiding Seminar STIAMI, Vol. III, No. 01, Februari 2016.

Ramadhan. A dan Salim Wilmar. A. (2019). Mencapai Keberlanjutan Ekosistem Laut Melalui Marine Spatial Planning (MSP) : Mungkinkah ?. Jurnal Kebijakan Sosek KP Vol. 9, No. 1 Juni 2019 : 11-21.

Ramdhan. M dan Arifin. T. (2013). Aplikasi Sistem Informasi Geografis Dalam Penilaian Proporsi Luas Laut Indonesia. Jurnal Ilmiah Geomatika. Vol. 19, No. 2 Desember 2013 : 141146.

Ramlan dan Erwinsyahbana. (2017). Konsep Penguasaan Mutlak Sumber Daya Alam Perikanan Indonesia Oleh Negara Dalam Mewujudkan Kesejahteraan Nelayan. Jurnal Litigasi, Vol. 18 (2), 2017, p. 301339.

Soekanto, S. (2006). Sosiologi Suatu Pengantar. Jakarta : PT. Raja Grafindo Persada.

Thomas, M. J. (1979). The Procedural Planning Theory of A. Faludi Planning Outlook, 22:2, page : 72-76. 